\title{
The idea of sustainable development in the landscape contemporary cities
}

\author{
Paweł Piotr Szumigała \\ https://orcid.org/0000-0001-8069-787X \\ pawel.szumigala@up.poznan.pl
}

\section{Piotr Urbański}

https://orcid.org/0000-0002-6924-3663

piotr.urbanski@up.poznan.pl

\section{Przemysław Tomczak}

https://orcid.org/0000-0001-6148-5329

przemystaw.tomczak@up.poznan.pl

\section{Miłosz Walerzak}

https://orcid.org/0000-0001-8089-0354

miłosz.walerzak@up.poznan.pl

\section{Sylwia Sosnowska}

https://orcid.org/0000-0001-9356-7433

sylwia.sosnowska@up.poznan.pl

Department of Landscape Architecture, Poznań University of Life Sciences

\section{Karolina Olenia Szumigała}

https://orcid.org/0000-0003-1935-7491

karolina.szumigala@gmai.com

Faculty of Architecture, Department of Landscape Architecture,

Poznań University of Life Sciences

\begin{abstract}
The article attempts to discuss the development of the idea of sustainable development in the landscape of cities on selected examples. The reasons for the current state of the townscape are analysed. EU and Polish legal acts in the field of landscape, environment and cultural heritage protection were reviewed. The examples presented in the article show that activities in the field of development and improvement of urban landscape have many aspects, both legal, environmental, social and economic. The current development of cities causes the development and urbanization of already existing green areas and agricultural land. Meanwhile, the spatial policy (in accordance with the idea of sustainable development of the urban landscape) attempts to compensate for the loss of greenery in many cases by afforestation of wasteland and creation of new areas of managed greenery: on revitalised (post-industrial) areas, coastal areas, introduces supplements to street greenery and realisation of new parks and green areas, as well as organising new forms of greenery on former farmland.
\end{abstract}

Keywords: sustainable development, urban landscape, legal acts, cultural heritage, landscape protection 


\section{Introduction}

When delving into the consideration of architecture, urban planning and landscape design within the framework of the widely understood idea of sustainable development, and thus adaptation to climate change, ecosystem services and reduction of energy consumption, attention should be paid to the landscape aspects of the transformed and designed urban space. Underestimated in recent decades, the role of green areas and water in shaping the residential environment is now becoming not only an aesthetic requirement. The share of green areas and water in urban development has an increasing influence on raising the urban and landscape standards of these areas. The aforementioned environmental components are also reflected in the economic zone of the investment, and in the context of the ongoing climate changes they are becoming an almost necessary condition of existence in the city. An indispensable condition for the correct and effective shaping of the landscape sphere and urban space are necessary changes in the general awareness of society and decision makers. The tasks posed by urban landscape design therefore take on a new local and global dimension. Economic and spatial development, which in many cases and in many areas takes an uncontrolled and chaotic form - has caused significant threats to ecosystems and cityscapes. The idea of sustainable development emerged only after humanity recognized and became aware of the resulting threats to future generations. Unfortunately, the perspective of economic profit, which still grips much of humanity, wins out over the idea of sustainability and prudent management, both of natural resources and the resources of the environment and the landscape of urban areas [30].

\section{State of research}

The current of research associated with urban landscape issues in the context of sustainable development includes numerous publications and analyses. Since 1992, following the announcement of the Rio de Janeiro Convention on Biological Diversity, this issue has been dealt with by many researchers who have dealt with this subject in various aspects, including: urban planning and ruralism - in terms of identifying the characteristics of regional buildings and urban areas (Trotsky-Leszczyńska, 2001; Łodźński, 2012; Trotsky-Leszczyńska and Nykiel, 2015; Szumigała, 2015, 2016, 2019) [38, 37, 12, 32, 33, 34]; describing the intensive development of landscape ecology and interdisciplinary research on the natural environment (Łuczyńska-Bruzda, 1997; Richling and Solon, 2002; Żarska, 2003; Matuszkiewicz, 2001) [13, 22, 43, 15]; cultural and historical - in terms of identification and analysis of culturally valuable areas, monuments, wooden architecture, historical analysis and perspectives of development of these areas (Szulc, 1995; Tkocz, 1998; Halamska, 2006, 62008; Małachowicz, 2007; Szmytke, 2014; Hill, 2017; Szumigała, 2019) [31, 32, 8, 9, 14, 25, 4, 34]. There was also a significant development of science in understanding, defining and methods of landscape analysis during this time (Wolski, 1998; Żarska, 2001, 2003; Rylke, 2002, 2011, 2013, 2016; Małachowicz, 2007; Chmielewski et al, 2015; Myga-Piątek, 2015; Szumigała, 2019) $[41,42,43,24,25,26,27,14,6,17,34]$. Aspects of urban biodiversity and green space as a basis for sustainable development are discussed (Bać 2012, Stangel 2013, Trzaskowska, 2015; Nawrotek, 2017) $[1,28,39,18]$. An important aspect of sustainable development is rational management of water resources (Januchta-Szostak, 2010; Wagner, Januchta-Szostak, Waack-Zając, 2014; Muszyńska-Jeleszyńska, 2013) [11, 40, 16]. Research has been conducted to assess the progress of the concept of sustainable development based on the identification and analysis of selected measurement indicators (Roszkowska, Filipowicz-Chmko, 2016; Teneta-Skwiercz, 2018) [23, 35]. Sets of principles for sustainable development and practical application of implementation guidelines are defined (Bać 2013, 2014; Jacob, Mage, Scerii, \& Steger, 2015; Przesmycka, 2015; Przesmycka, Napieralska, 2016) $[2,3,10,20,21]$. The principles of sustainable development were also discussed in legal aspects, among others through the prism of Polish legislation. The issue of erroneous linking of the principle of sustainable development only with the branch of environmental law was raised (Stoczkiewicz, 2001; 
Olejniczak, 2016) $[29,19]$ and on the implementation of EU principles into Polish law and utopian aspects of Polish law on sustainable development (Szmytke, 2014; Bukowski, 2005, 2012; Nawrotek, 2017) ${ }^{1}$ [30, 4, 5, 18].

\section{Landscape in European and Polish legal acts}

Consideration of the design and shaping of urban landscapes in the context of the idea of sustainable development should begin with a review of the legal acts that concern this issue. In this approach to the subject, 1992 becomes a watershed date. It was on 5 June 1992 that the Convention on Biological Diversity was adopted in Rio de Janeiro, along with numerous directives and regulations. The aim of the Convention was to ensure and guarantee sustainable development in various areas of the continent's economy and life, and in terms of environmental protection, to preserve natural habitats and wild species of fauna and flora. The Convention on Biological Diversity is also the culmination of previously adopted conventions:

- The 1971 Framework Convention, as revised in Paris in 1982, and the 1987 Emergency Convention of the Participating Parties in Regina, Canada, which aimed to ensure the protection of wetlands of

1 Bać A., Zielone miasta jako szansa na zrównoważony rozwój na przykładzie Vancouver, Politechnika Wrocławska, 2012; Bać A., Współczesny wizerunek Vancouver - polityka, edukacja i architektura, Zeszyty Naukowe Politechniki Poznańskiej, Architektura i Urbanistyka, 2013, z. 29, 17-23; Bać A., Idea zrównoważenia i jej wybrane przejawy. Architectus, 2014, 2(38); Bukowski Z., The concept of sustainable development in Polish law, [in:] Sustainable development from utopia to human rights, A. Papuziński (ed.), Bydgoszcz 2005; Bukowski Z., Sustainable development in the system of law, Torun 2012; Chmielewski, T.J., Myga-Piątek U., Solon J., Typology of current landscapes Polish. Geographical Review, 2015, 87(3), 377-408; Górka A., On the utility of the village vision. In: Gosidło K., Twardoch A. (eds.), Architecture, environment, society, contemporary economy (pp. 84-97); Gliwice: Silesian University of Technology Publishing House, 2017; Halamska M., Poland: a new shape of rural-urban relations. Yearbooks of Rural Sociology, 2006, 26, 138-162; Halamska M., Rural transformation. Warsaw: Development Academy EUROREG Regional Advisory Council, Warsaw University, 2008; James P., Magee L., Scerri A., Steger M.B., Sustainable urban development in theory and practice: circles of sustainability, 2015, London: Routledge.8; Januchta-Szostak A., The city in symbiosis with water. Town and Water Symbiosis. Technical Journal, Architecture, 2010, R. 107, Z. 14, 6-A2, 95-102; Łodzinski P., Continuation of regional tradition in single-family residential architecture as one of the conditions of spatial order. Architecture et Artibus, 2012, 1, 18-24; Łuczyńska-Bruzda M. Natural elements of the environment ( $4^{\text {th }}$ ed.), Kraków: Wydawnictwo Politechniki Krakowskiej, 1997; Malachowicz E., Conservation and revalorization of architecture in cultural environment (4 ${ }^{\text {th }}$ ed., pp. 21-503), Wrocław: Oficyna Wydawnicza Politechniki Wrocławskiej, 2007; Matuszkiewicz W., Guide to the identification of plant communities of Poland, Warsaw: Wyd. Science. PWN, 2001; Muszyńska-Jeleszyńska D. Riparian areas in the aspect of urban development and revitalization. Kazimierz Wielki University. 2013, http://repozytorium.ukw.edu.pl/ handle/item/1446 [14]; Myga-Piątek U., Landscape policy of Poland - at the threshold of implementation. Overview Geographic, 2015, 87(1), 5-25; Nawrotek E., Biodiversity conservation and new legal solutions for the protection of green areas and woodlands. Studia luridica Lublinensia vol. XXVI, 1, 2017. DOI: 10.17951/sil.2017.26.1.315; Olejniczak E., The principle of sustainable development in the Polish legal system - selected issues. Environmental Law Review 2016, 2. DOI: http://dx.doi.org/10.12775/PPOS.2016.013; Przesmycka E., Spatial and architectural transformations of degraded and restored towns in the Lublin region. In: Degraded and restituted towns in Poland: origins, development, problems = Cities degraded and restituted in Poland: origins, development, problems (eds.) Robert Krzysztofik, Mirek Dymitrov. Gothenburg: University of Gothenburg, 2015. pp. 209-247; Przesmycka E., Napieralska Z.Z., City landscape: present state and problems with protection of post-war single family house complexes from uncontrolled modernizations, W: Landscape as impulsion for culture: research, perception \& protection. Vol. 3, Problems of protection \& sharing / [eds. Kołodziejczyk P., Kwiatkowska-Kopka B.] Kraków: Institute of Archeology, Jagiellonian University in Kraków, Institute of Landscape Architecture, Cracow University of Technology, 2016, s. 99-108; Richling A., Solon J., Landscape ecology (4 ${ }^{\text {th }}$ ed.), Warsaw: Wyd. Science, PWN, 2002; Roszkowska E., Filipowicz-Chomko M., Ocena realizacji koncepcji zrównoważonego rozwoju województw Polski w zakresie poziomu rozwoju społecznego w roku 2005 oraz 2013, Optimum, Studia ekonomiczne, 2016, 3 (81); Rylke J., Principles of cultural landscape assessment, In: Szyszko J., Rylke J., Jeżowski P. (eds.), Assessment and valuation of natural resources (pp. 214-235), Warsaw: SGGW Publishing House, 2002, 224, Rylke J., Cultural Landscape. Maps of Meaning. In: Bernat S. (ed.), Intangible values of cultural landscapes (pp. 278-287), Sosnowiec: Cultural Landscape Commission PTG, 2011; Rylke J., The cultural landscape of Poland, In: Assessment and valuation of natural resources (pp. 224-240), Warsaw: Wyd. SGGW, 2013; Rylke J., The natural context of landscape design. Bionics 40, In: Dreszer S.(ed.), 40 years of bionics at the University of Arts in Poznań. Landscape design as an indispensable part of natural environment protection, Poznan: University of Arts in Poznan, 2016; Stange M., Kształtowanie współczesnych obszarów miejskich w kontekście zrównoważonego rozwoju, Gliwice, Wydawnictwo Politechniki Śląskiej 2013; Stoczkiewicz M., The principle of sustainable development as a principle of law, Law and Environment 2001, 1, Szmytke R., Methods of analysis of morphology and physiognomy of settlement units, Wrocław: University of Wrocław, 2014; Szulc H., Morphogenesis of rura settlements in Poland, Warsaw: PAN, 1995; Szumigała P., Spatial codes in the context of sustainable development of selected communes of Wielkopolska, Zeszyty Naukowe Uniwersytetu Szczecińskiego, Studies and Papers of the Faculty of Economic Sciences and Management, 2015, 42(2), 219-232; Szumigała P., Space management and management in the context of sustainable development - Diagnosis of the state of space in Poland. In Farming in the $21^{\text {st }}$ century (96-111), Szczecin: Wyd. University of Szczecin, 2016; Szumigała P., Diagnosis of the state of protection of historical urban structures-landscape areas of Poznań district on the basis of Historical Spatial Codes method and records of local spatial management plans, Poznań, Publishing House of the University of Life Sciences in Poznań, 2019, 387; Teneta-Skwiercz D. Indicators of sustainability measurement - Poland in comparison with the European Union countries. Scientific papers of the Economical University in Wroclaw. Research papers of Wrocław University of Economics, 2018, 516; Tkocz J., Spatial organization of villages in Poland, Katowice: Wydawnictwo Uniwersytetu Śląskiego, 1998; Trocka-Leszczynska E., Architectural identity of rural housing in the Sudeten region. Quarterly Journal of Architecture and Urban Planning, 2001, 46(3), 299-308; Trocka-Leszczynska E., Nykiel J., Possibilities of preserving the features of regional architecture in Kotlina Kłodzka. Building Materials, 2015, 11, 169-171 [35]; Trzeskowska E., Protection of urban biodiversity as one of the principles of implementing sustainable development. Urban studies, 2015, Volume19; Wagner I., JanuchtaSzostak A., Waack-Zając A., Tools for planning and strategic management of water in urban spaces Sustainable Development - Applications No. 5, 2014; Wolski P., (ed.). Protection of natural and cultural heritage in Poland, Warsaw: SGGW Publishing House, 1998; Żarska B., Study of landscape protection - methodics of working out for various areas. Annals of Warsaw University of Life Sciences - SGGW, Horticulture and Landscape Architecture, 2001, 22, 111-122; Żarska B., Landscape Conservation (ed. II zm, pp. 11-183), Warsaw: SGGW, 2003. 
international importance through the promotion of state action, international cooperation and the establishment of reserves;

- The Paris Convention for the Protection of the World Cultural and Natural Heritage of 16 November 1972, which paid particular attention to the protection of monuments, building complexes and historic sites in terms of cultural heritage, and in terms of natural heritage created a framework for the protection of natural monuments, geological and physio-graphic formations and sites and zones of natural landscape and environment by setting their strict boundaries;

- The Washington Convention - also known as the 1973 CITES Convention, which aimed to control and regulate trade in wild animals to be preserved for future generations;

- The Bern Convention on the Conservation of European Wildlife and Natural Habitats adopted on 19 September 1979 in Bern, which prescribes the conservation of all wild species and natural habitats with particular emphasis on threatened and endangered species;

- European Convention for the Protection of the Archaeological Heritage in La Valetta of January 16, 1992, which required signatories to the convention to guarantee funds in state budgets for the protection of cultural heritage and for research and hazard analysis and documentation of these activities;

- Bonn Convention on the Conservation of Migratory Species of Wild Animals, done at Bonn on 23 June 1979. In Poland the Convention entered into force on 1 May 1996. The aim of the Convention is to protect migratory wild animals, which are an irreplaceable part of the natural environment. Species of which a significant number of individuals cyclically and predictably cross state jurisdictional boundaries in different life cycles are considered "migratory". The ASCOBANS and EUROBATS Agreement on the conservation of cetaceans and bats was signed under this convention.

- The Convention on Biological Diversity, drawn up in Rio de Janeiro on 5 June 1992, was ratified by Poland in 1996. The Convention aims at the conservation of biological diversity, the sustainable use of its components and the fair and equitable sharing of benefits arising from the utilisation of genetic resources, including through appropriate access to genetic resources and appropriate transfer of relevant technologies, taking into account all rights over those resources and technologies, as well as adequate funding. A manifestation of the dynamic growth of economic development in Europe was the signing of the founding act of the European Union in Maastricht, and one of the first documents on environmental protection was the previously mentioned Convention on Biological Diversity.

The most important legal acts on landscape protection at the EU level include the European Landscape Convention adopted in Florence on October 20, 2000, which contained very important arrangements for landscape management, concerning among others: interpretation of the term and definitions of landscape concepts, landscape policy, landscape objectives and quality, landscape protection, landscape management and landscape planning.

It is in the European Landscape Convention that the broad - conceptual definition of landscape - as an area perceived by people, whose character is a result of action and interaction of natural and/or human factors, is included. An important aspect, according to Article 11 of the European Landscape Convention is the institution of the Council of Europe Landscape Award, which promotes, recognizes and rewards state and non-state institutions, local and regional bodies for their activities, achievements and significant contributions to the field of landscape protection, management and planning. Meanwhile, the World Heritage List also plays an important role in heritage conservation, with 1121 sites from 165 countries as of July 2019, including 869 cultural, 213 natural and 39 mixed heritage sites. However, the most important supplement to these documents are executive acts - regulations and directives of the EU, on the basis of which..." member States shall establish their legal basis for landscape conservation, planning and design".

The most important Polish legal acts regulating the principles of sustainable development include:

- The Constitution of the Republic of Poland of 2 April 1997, and Article 5 of the Fundamental Law says: "The Republic of Poland shall safeguard the independence and inviolability of its territory, ensure freedom and human and civil rights and the security of its citizens, safeguard the national heritage and ensure environmental protection in accordance with the principle of sustainable development", and Article 86: "Every citizen is obliged to take care of the state of the environment and is responsible for the deterioration caused by him. The rules for this liability are defined by statute." 
- The 2030 Agenda for Sustainable Development (Transforming our world: the 2030 Agenda for Sustainable Development), was adopted in 2015 by 193 countries of the United Nations (including Poland) and includes 17 Sustainable Development Goals (SDGs) and 169 related targets, which cover the three dimensions of sustainable development - economic, social and environmental.

- Act of 24 April 2015, amending certain laws in connection with the strengthening of landscape protection tools (Journal of Laws 2015, item 774),

- Act on revitalization and amendments to some other acts of 9 October 2015 (Journal of Laws 2015, item 1777).

- The Nature Conservation Act of 16 April 2004 sets out the objectives, principles and forms of protection of animate and inanimate nature and landscape.

- The Act on protection and shaping of the environment of $\mathbf{3 1}$ January 1980 lays down the principles of protection and rational shaping of the environment, aiming to ensure favourable living conditions for the present and future generations and to realise the right to use the resources of the environment and to preserve its value.

- Hunting, as an element of environmental protection, within the meaning of the Act means protection of game animals and management of their resources in accordance with ecological principles and principles of rational agricultural, forest and fishery management.

- Carpathian Convention, the Framework Convention on the Protection and Sustainable Development of the Carpathians, made in Kiev on 22 May 2003, was ratified by Poland in 2006 (Journal of Laws 2007, No. 96, item 634). The aim of the Convention is to pursue a comprehensive policy and to cooperate for the protection and sustainable development of the Carpathians to improve the quality of life, strengthen local economies and communities and preserve the area's natural values and cultural heritage.

In accordance with the Rio Declaration on sustainable development and subsequent postulates, spatial activities and development should respect landscape and cultural values. In the development of this issue and after a deeper analysis of the idea, preserving and protecting the present forms of landscape for future generations should be considered as one of the main objectives of landscape design and protection, including the landscape of cities.

On the other hand, the development of civilization is a necessity, but it is currently causing irreversible changes in landscape structures almost all over the globe. The distribution of these changes is not uniform. This phenomenon, raises many concerns about the shape of the landscape in the future. This situation raises questions about the role and tasks that should be fulfilled by landscape design within the idea of sustainable development and its impact on the urban landscape.

\section{Research methods and material}

We conducted the research using quantitative and qualitative methods and on the basis of comparative analyses. In the first stage, we conducted an analysis of the state of research and a review of European and Polish legal acts in the aspect of sustainable development. Then, we conducted analyses of examples for two groups of cities: foreign and Polish. We used here the method of delimitation and typological analysis of the diversity of the analyzed examples - the method: a case study. For a group of foreign cities, we carried out a recognition of the principles and elements of area development in the context of the idea of sustainable development in the planning and development of selected urban areas. We based our research of characteristic features on publicly available rankings. For several selected cases of cities, we investigated the share of green areas in the urban area, the amount of green areas per capita and the size of the urban area covered by tree crowns. We have presented the results of these analyses in the form of synthetic tabular summaries [Tables 1 and 2]. In the group of Polish cities, we selected a representative group of six largest cities: Warsaw, Kraków, Łódź, Wrocław, Poznań and Gdańsk. For this group of cities, we studied the share of green areas in the urban area, the amount of areas per capita, and the shares in the urban area for four characteristic forms of greenery. We summarized the results of these studies in the form of four tables [Tables 3, 4, 5, and 6]. We considered that the above coefficients define the state of advancement of the idea of sustainable development in shaping the landscape of 
urbanised areas, as green areas are the main determinant of landscape standards of urbanised space. In most cities, it is still a scarce element and under constant degradation.

\section{Urban landscape in the context of the idea of sustainable development}

According to the idea of sustainable development in landscape design, spatial development, especially development of new built-up areas and industry, should be carried out in the form of long-term transformations aiming to create a landscape while preserving environmental biodiversity and cultural and aesthetic values at a level guaranteeing cultural continuity of regions, towns and villages for the next generations. Landscape is the manifestation of all the elements of the space shaping process. Performing:

- as a component / element - i.e. material / material: greenery, water, urban structure;

as an instrument / tool - i.e. a project, a concept, an idea;

- and as an effect / result - that is, as a realized, actual space.

If we create urban areas, then the landscape of the city, village is created by the urban planner, landscape architect. Thus, the landscape aspect occurs at all scales of spatial planning and is inextricably linked to land use policy and management.

Currently there are already many realized examples of urban space where the idea of sustainable development in landscape design is realized in new concepts of urban development, which grow out of criticism of the phenomena of intensive and often uncontrolled development, including, among others, industrial and residential development. In these cases, it is essential to properly design the relationship between green spaces, waters and intelligently managed other functional elements of urban structures, which are the basic components of the landscape. It is also important to maintain a high level of environmental protection: minimising carbon emissions, creating parks and open green spaces, using renewable energy sources, reducing water consumption, recycling and disposing of waste using advanced scientific and technological methods. Contemporary spatial and landscape concepts of sustainable urban development already take into account energy-efficient public and private transport networks - from reducing the motivation to use personal vehicles, to modernising street lighting, to implementing intelligent traffic signals, to creating a safe cycling network for city dwellers. Reducing the number of internal combustion vehicles in the city results in, among other things, reduced exhaust fumes, reduced need for wide streets and long traffic axes, and increased pedestrian zones and crossings. It is also important to ensure a high level of security through public awareness of threats (information campaigns), as well as through technological support - a network of video cameras, brightly lit public places, alarm systems and increasing the mobility and effectiveness of intervention services. Examples of the influence of the idea of sustainable development on the creation of the landscape of cities are the concepts of building new cities and realization and reconstruction of fragments of urban structures of already existing metropolises, among others:

Masdar City, is an example of the implementation of a new urban structure - a new city with an area of $600 \mathrm{ha}$, planned according to the idea of "ecological utopia". The city is being built in the desert landscape of Abu Dhabi. The spatial plan of the city is based on the layout of the ancient city walls on a square plan divided by a green belt. Masdar City aims to be a global benchmark for a fully green urban system, where electricity demand will be met from $100 \%$ renewable sources with no carbon emissions into the atmosphere. The energy supply is to be guaranteed by mobile "umbrellas" - structures that will follow the sun while providing shade for the public space of the city square. The umbrellas are state-of-the-art giant solar power plants that will store heat and electricity to then release at night when the umbrellas are closed. Another spatial and landscape solution is to be "angular" elevations, reflecting and scattering sunlight, built of materials adapted to climatic conditions with large temperature amplitudes. Gardens are planned on the roofs of the development to produce food (vegetables, fruits, herbs) produce electricity and heat and reuse organic waste. Communication in the city will be provided by public transport and electric individual vehicles [Fig. 1]. 

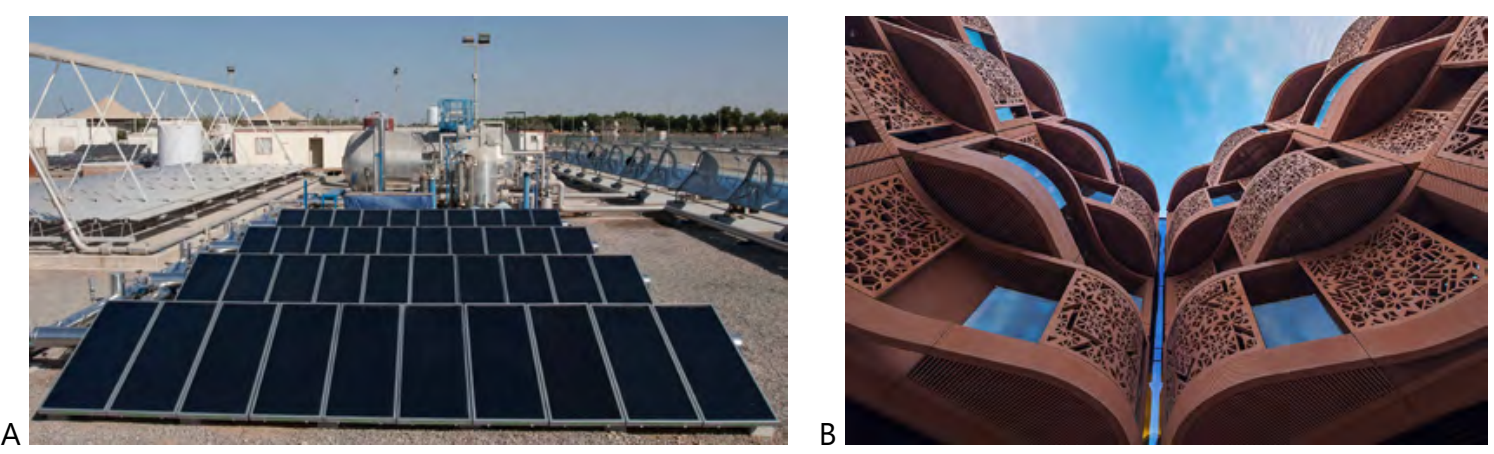

Fig. 1. Desert Masdar City, A - photovoltaic installations, B - development structures

Sources: https://commons.wikimedia.org/wiki/File:Masdar_city_under_construction_2012.jpg; 21.04.2021, https://commons. wikimedia.org/wiki/File:MT-Power_Masdar_City.jpg, 14.04.2021.

Songdo City, is another example of a city erected from scratch on an island in the Yellow Sea according to the master plan of Kohn Pedersen Fox Associates ${ }^{2}$. Sangdo City, is a half-million-dollar ultra-modern business city designed to reflect the South Korean government's efforts to create and promote low-carbon and environmentally friendly policies. The city was designed according to seven principles: 1 - open and green space; 2 - convenient transportation; 3 - sustainable water consumption; 4 - storage and disposal; 5 - carbon saving and minimising energy consumption; 6 - recycling; 7 - sustainable urban management. Songdo City is an urban structure built according to sustainable development principles. The share of green areas is more than $40 \%$ of the city area and all main buildings meet the requirements of the green certification "LEED". The city's water system is divided according to environmental engineering principles into three parts - fresh water, wastewater and grey water (used for irrigation and toilets). Every building in the city has been equipped with its own recycling and dirty water collection system. The concept of management and control of the city provides for its complete computerization. Modern surveillance and security systems have been implemented, which by means of numerous cameras look for traces of fire, possible accidents on the road, check license plates in search of stolen vehicles, and take care of the health of citizens by monitoring the state of air pollution. Innovative systems have been introduced to control and reduce electricity consumption, such as streetlights that automatically adjust to the number of people on the street. Transport infrastructure is also an extremely important element. The city has a subway line, over 26 kilometres of bike lanes, an extensive network of electric vehicle charging stations, and $95 \%$ of parking is underground. City cars will be equipped with in-car license plates that will turn off traffic lights if they do not detect other cars on the roadway. This new urban structure pretends to be a modern business centre on a par with Singapore, Hong Kong and Shanghai [Fig. 2].
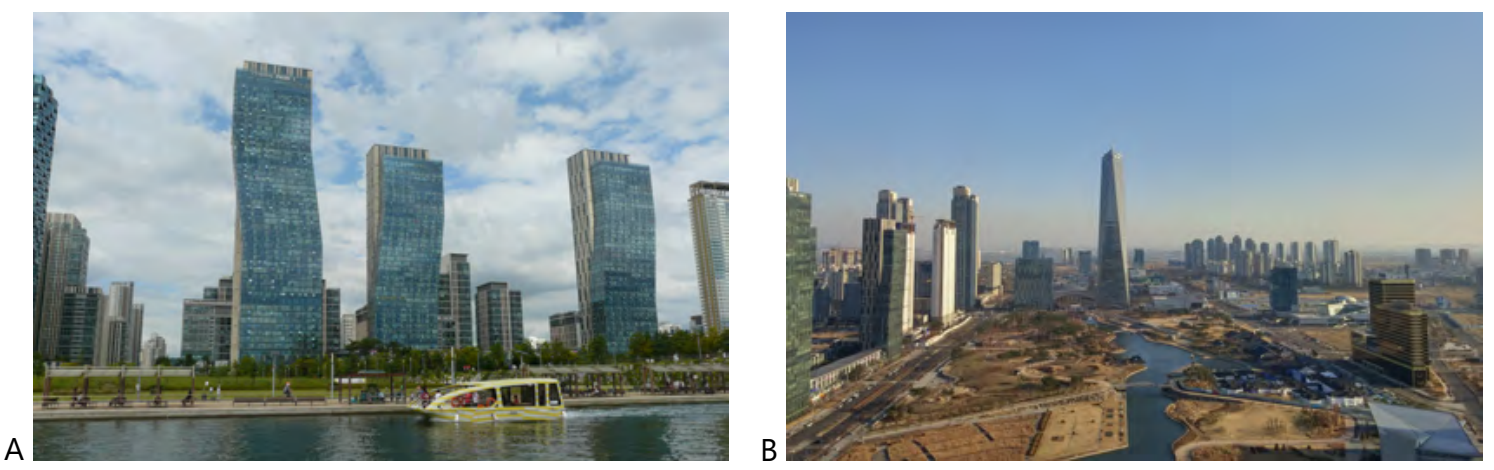

Fig. 2. Songdo business city, A, B - large areas of water and urban greenery visible

Sources: https://commons.wikimedia.org/wiki/File:Songdo_International_Business_District_08.JPG, 10.06.2021; https:// pl.m.wikipedia.org/wiki/Plik:Songdo_IBD_Incheon_2014_HDR_2.jpg, 20.04.2021 
Almere, is the youngest city in the Netherlands and its landscape is designed with sustainability in mind. Almere was designed from the ground up as a Green City and is a contemporary development of Howard's idea of the Garden City. The intensity and consistency of action by both the city authorities and a range of institutions and designers to create a new "green" landscape and spatial structure on this scale. The idea is finding general social acceptance. City planning and landscape design were based on principles:

diversity - conceived as a feature of solidarity-based ecological, social and economic systems (a city rich in diversity);

- place and context - build on your own strength and mutual benefit with surrounding communities in the city;

- shared city and nature - striving for unique and sustainable landscape combinations of the urban fabric and the natural fabric in order to raise humanity's awareness of its relationship with nature;

- change - evolution of the city, flexibility and adaptability of development plans for future generations;

innovation - using the latest technology;

- healthy systems - the conscious and rational use of the interdependence of ecological, social and economic components of the landscape;

- subject - through maintaining local identity and subjectivity gaining the driving force to create and maintain the unique potential of the city [Fig. 3].
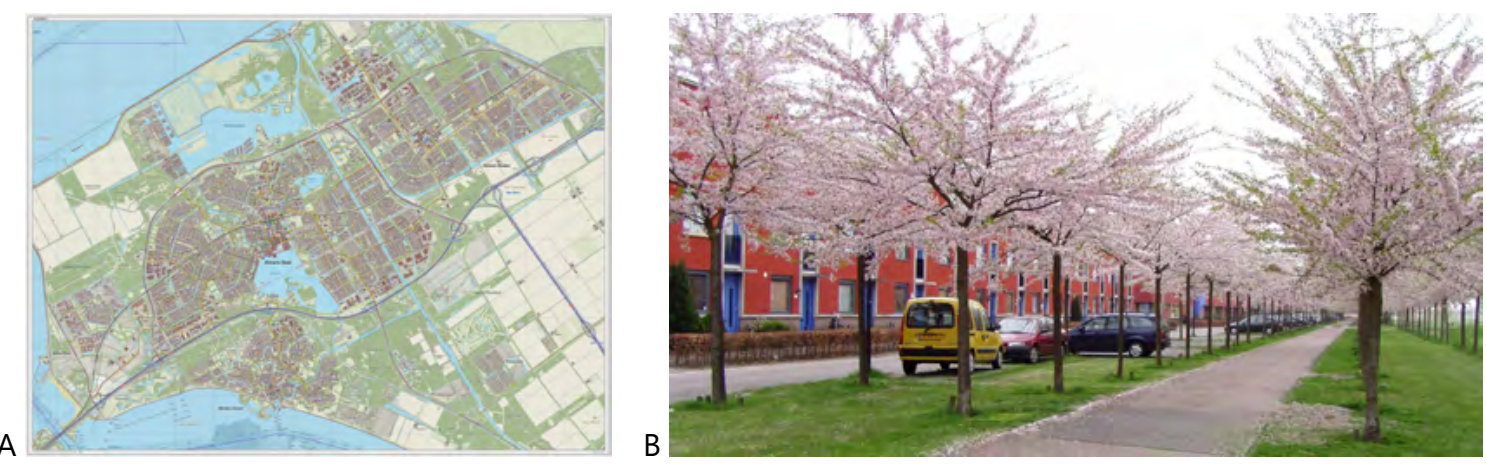

Fig. 3. A - city plan of Almere, B - landscape of the urban fabric

Sources: https://commons.wikimedia.org/wiki/File:Almere,_the_Netherlands_2004.jpg, 10.06.2021; https://commons.wikimedia. org/wiki/File:Regenboogbuurt_terracottastraat_2006_bloesem.JPG,10.04.2021.

London - Lower Lea Valley, is a part of East London comprising the quays of the River Lea. The Lea Valley is a symbol of the concentration of heavy industries, which has been spatially, economically and socially degraded. The recovery of the landscape and environmental values of the Lea river valley was the basis of a new concept according to the idea of sustainable development. An essential element of landscape design in this case was the creation of a network of green areas - parks, green spaces, nature reserves and riverside floodplains. This preserves and enhances the Lower Lea Valley landscape qualities. By enriching the biodiversity of existing and new green spaces, unique fauna and flora resources have been protected.

Neckervorstadt exemplifies new concepts of urban landscape design according to the principles of "ecophilosophy" using new environmentally friendly solutions. The idea of this plant need to balance between biotic, natural and abiotic elements. An important environmental component of this urban structure is water. The use of the latest technology makes it possible to introduce buildings close to water. This principle is at the same time a characteristic element of this concept of landscape planning for new urban structures. In this case, according to the idea of sustainable development, in the process of landscape design and spatial planning, each element is treated as an organism coexisting with its natural surroundings.

The Delaware River Front in Philadelphia is a widely discussed example of a concept created according to the "landscape urbanism" method of urban planning. The basis for these activities is a holistic approach to cityscape planning, in which the analysis of the system of individual landscape connections in the city, rather than a single structure or a single building, is the basis [Fig. 4]. 


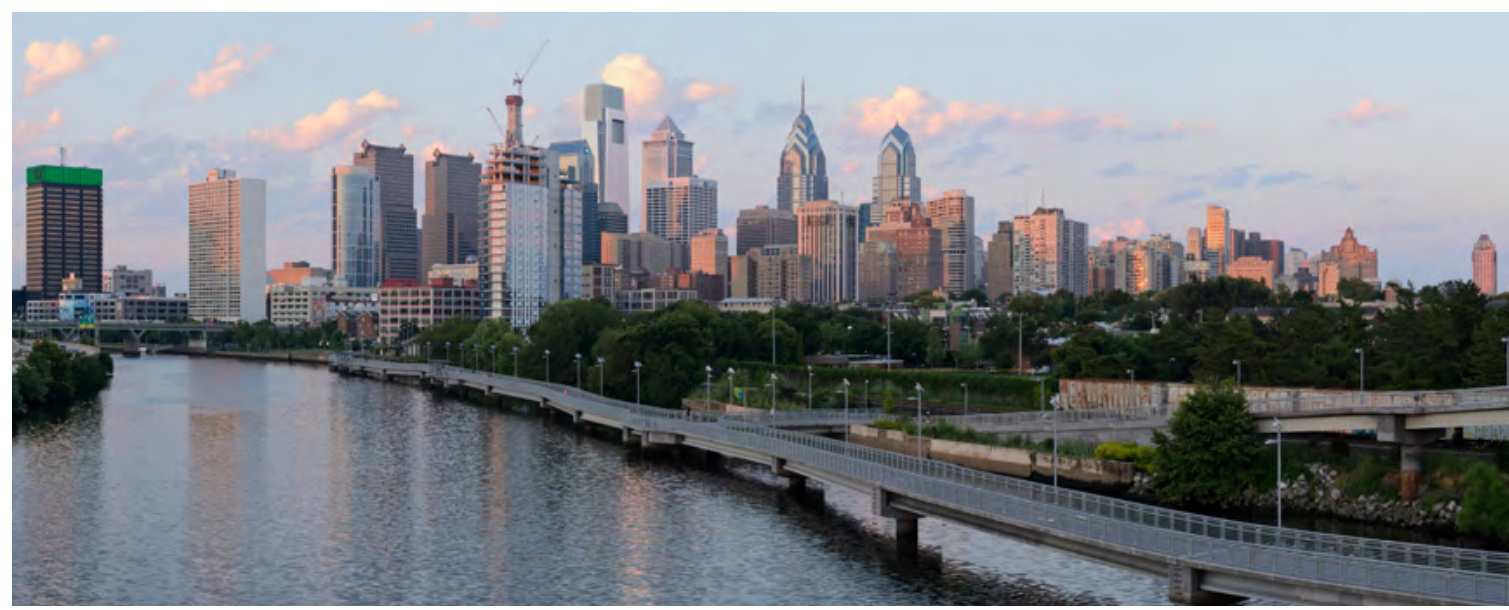

Fig. 4. Philadelphia - view of the Delaware River Front

Source: https://commons.wikimedia.org/wiki/File:Philadelphia_from_South_Street_Bridge_July_2016_panorama_2.jpg, 10.04.2021.

Randstast, embodies the idea of sustainable development and cityscape, whose main spatial consideration is extensive development. The planned development of the city envisages a Megalopolis in the Netherlands. It is supposed to be a large "green" metropolis with low population density, equipped with acres of "urban agriculture", "garden-parks" for recreation and "eco-roads". Movement is to be satisfied by "eco-cars". The Randstast development provides for the systematic expansion of park and garden residential environments with densities similar to the region's averages. The long-term spatial and landscape assumptions are the processes of continuous restoration of the environment to the state of a controlled ecosystem before human interference.

Various rankings are also carried out in order to classify urban centres in terms of the amount of green areas. Internet tools such as Google Street View (GSV) and satellite image analysis are used for this research. Based on this, the panoramas are analysed and the Green View Index (GVI) is calculated. Also used is the Husqvarna Urban Green Space Index (HUGSI), which is created by Husqvarna in collaboration with Overstory.ai. Such a report aggregates multiple data points captured in 2019 for 155 cities in 60 countries to develop the HUGSI 2020 index. HUGSI is determined based on - Global Human Settlement Layer (GHS-POP) [Table 1]. On the other hand, Table 2 presents the ranking results for the canopy cover index.

Table 1. The ranking of the greenest cities in the world was prepared on the basis of satellite maps - in addition to public green areas it also includes private green areas

\begin{tabular}{|c|c|c|c|c|c|c|}
\hline City & Country & Area in $\mathbf{k m}^{2}$ & $\begin{array}{l}\text { Population in } \\
\text { thousands }\end{array}$ & $\begin{array}{c}\text { City area per } \\
1 \text { inhabitant } \\
\mathrm{m}^{2}\end{array}$ & $\begin{array}{c}\text { Green } \\
\text { area per } 1 \\
\text { inhabitant } \mathbf{~ m}^{2}\end{array}$ & $\begin{array}{c}\text { Share green } \\
\text { areas in the } \\
\text { city area* }\end{array}$ \\
\hline Charlotte & $\begin{array}{l}\text { USA } \\
\text { (Północna } \\
\text { Karolina) }\end{array}$ & 651 & 784,3 & 830 & 560,1 & $68 \%$ \\
\hline Durban & RPA & 1032 & 3300 & 312,7 & 185,8 & $59 \%$ \\
\hline Wilno & Litwa & 204 & 477,9 & 426,9 & 263 & $62 \%$ \\
\hline Dortmund & Niemcy & 261 & 573 & 455,5 & 264,6 & $58 \%$ \\
\hline Kraków & Polska & 261,9 & 718 & 364,8 & 207 & $57 \%$ \\
\hline Stuttgart & Niemcy & 191 & 617 & 309,6 & 182,6 & $59 \%$ \\
\hline
\end{tabular}

*Green View Index calculated from Google Street View (GSV) panoramas. 2015 data based on Global Human Settlement Layer (GHS-POP) using urban boundaries as defined in the Husqvarna Urban Green Space Index (HUGSI). 
Table 2. Wooded area in selected metropolises of the world. The program allows to calculate the area of the city covered by tree crowns on the basis of data from Google Streeat View and satellite images

\begin{tabular}{|c|c|c|c|}
\hline Position & City & State & Covering the city area with tree crowns \\
\hline 1 & Tampa & USA (Floryda) & $36,1 \%$ \\
\hline 2 & Singapur & & $29,3 \%$ \\
\hline 3 & Oslo & Norwegia & $28,8 \%$ \\
\hline 4 & Vancouver & Kanada & $25,9 \%$ \\
\hline 5 & Sydney & Australia & $25,9 \%$ \\
\hline 6 & Montreal & Kanada & $25,5 \%$ \\
\hline 7 & Durban & RPA & $23,7 \%$ \\
\hline
\end{tabular}

Source: Treepedia http//senseable.mit.edu/treepedia.

The influence of the idea of sustainable development is also visible in the creation of the landscape of Polish cities:

Warsaw is a city which owes its unique layout of the green system to its location on the Vistula River which, together with the coastal greenery of exceptional biodiversity, is the main ecological corridor. Green belts can also be found along the Wilanówki River, the Długa River, the Żerań Canal and other smaller watercourses. In 2020, the city joined the European Bank for Reconstruction and Development's Green Cities programme to develop a sustainable city strategy ${ }^{3}$. The result is the Environmental Protection Programme for the Capital City of Warsaw for 2021-2024, adopted in April 2021. In addition to the permanent development of green areas, the document places great emphasis on the establishment of new forms of nature protection, which are to effectively stop the expansion of construction projects into naturally valuable areas or areas important for the green area system. However, it is noteworthy that in recent years the compensation of biologically active surface in architectural projects has been increasing. It should be noted, however, that in recent years the compensation of biologically active surface in architectural projects is more and more often done by installing green roofs. There were 1306 green roof buildings in the city in 2019 with a total area of 52.3 hectares ${ }^{4}$.
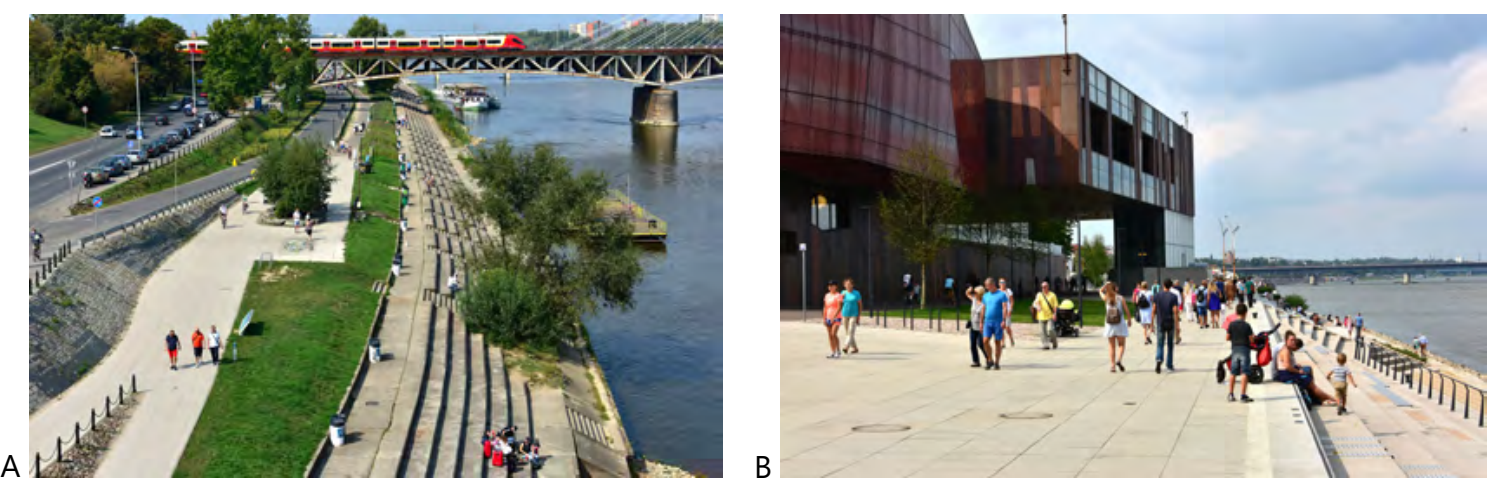

Fig. 5. A and B - Vistula Boulevards in Warsaw

Source: https://upload.wikimedia.org/wikipedia/commons/2/24/Bulwary_wi\%C5\%9Blane_w_Warszawie_2017a.jpg, 14.06.2021.

Kraków is a good example of a conscious, planned and long-term approach to the role of green areas in the idea of sustainable urban development. In 2017, the municipal authorities, together with a group of external experts, developed the document Directions for the Development and Management of Green Areas in Krakow for 2017-2030, in which the resources of green areas were analyzed in detail and precise directions

3 https://www.um.warszawa.pl/aktualnosci/podsumowanie-2020-troska-o-tereny-zieleni-miejskiej-niezmiennie-jednym-z-priorytet-w-mia, 12.06.2021.

4 https://bip.warszawa.pl/NR/exeres/CA8EF8BF-F40C-4511-8C7A-1EBF054EE365.htm, 12.06.2021 
for actions aimed at their dynamic development were set. Even before its adoption, the processes of acquiring new land were intensified. The proposed concept of the greenery system is based on two basic forms: developed urban greenery and areas of ecological and landscape greenery. The main element of the whole system is the system of river parks with the central Vistula Valley and the system of fortress greenery of the Krakow Fortress. In 2016, the City acquired 34.6 acres for the development of three parks which is a significant increase from previous years (2.29 acres in 2014 and 2.93 in 2015). At the same time, the city's budget for maintenance, redevelopment and acquisition of new land has been significantly increased ${ }^{5}$. This document was appreciated and recognized as an example of good practice by NIK auditors ${ }^{6}$. In 2018, another document was adopted in the city, the District Programme for Increasing the Forest Cover of the City of Krakow for 2018-2040. The result of these actions is a successive and significant increase in forest area ${ }^{7}: 1370.8$ in 2018, 1377.8 in 2019, 1421.14 in 2020, 1497.3 in 2021. The improvement in the amount of green areas in Krakow was therefore largely influenced by the positive actions of the city authorities.

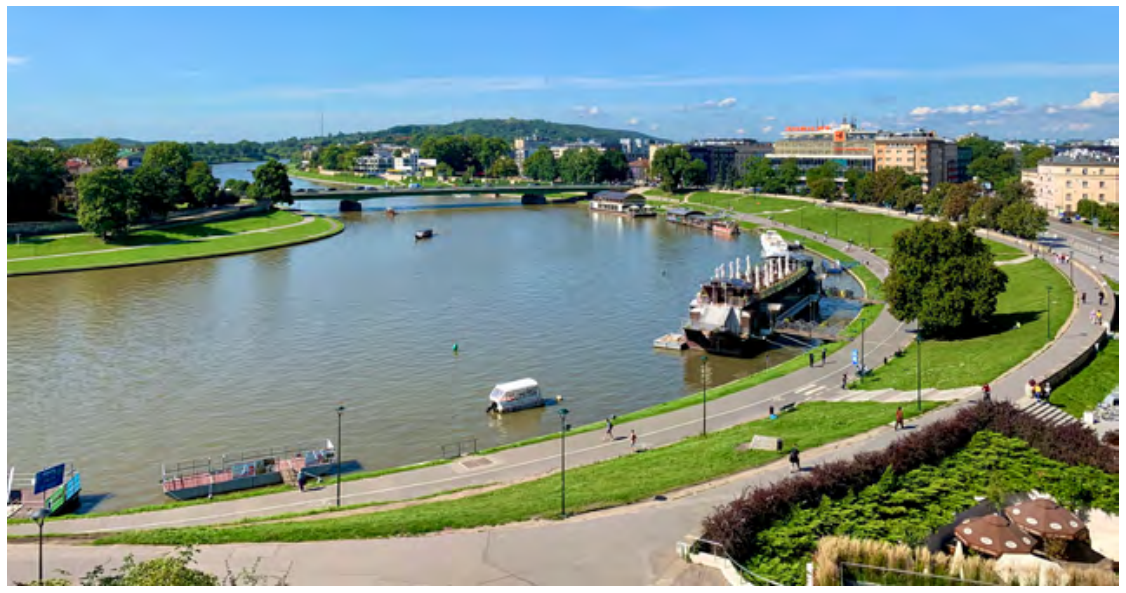

Fig. 6. Vistula Boulevards in Krakow

Source: https://pl.wikipedia. org/wiki/Krak\%C3\%B3w\#/ media/Plik:Views_from_Wawel_hill,_Krak\%C3\%B3w,_Poland,_2019,_06.jpg, 14.06.2021.

Wrocław lies in the Silesian Lowlands, on the Odra River and its four tributaries - the Bystrzyca, the Olawa, the Sleza and the Widawa. Such an expansive hydrographic system gives the city extraordinary scenic and environmental values and exemplifies efforts to introduce the concept of sustainable development in riverfront land use - the Sustainable Development of Municipal Waterfronts (ZRMFW). This programme contains ten principles ${ }^{8}$ and the sustainable development of riverside areas is one of the greatest urban and cultural challenges for contemporary riverside cities:

- Principle 1 - Protecting water quality and the environment

A prerequisite for the activation and development of water fronts is high surface water quality, which depends on water management conditions in the valley and the entire catchment. The transformation of river valleys should take into account the improvement of the environment's capacity for regeneration and self-purification Principle 2 - Waterfronts are an integral part of the urban fabric

Riparian areas should be an integral part of the city and contribute to improving its life span. Water as a component of the urban landscape should be used for specific functions such as water transport, leisure, sport and recreation, entertainment and culture, and to enhance urban green structures.

- Principle 3 - Historic identity shapes waterfront character

Shared heritage of the city and the river and related events, special objects architecture and natural resources, should constitute the character and content of the waterside landscape. Preserving the industrial past is an integral part of a sustainable reconstruction. 
Principle 4 - Priority to functional diversity

Waterfronts should be characterized by a variety of cultural, commercial, and residential functions, with priority given to those uses that require direct access to water. Housing developments should be functionally and socially diverse.

- Principle 5 - Condition of public access to water

Waterfronts should be physically and visually accessible to residents and tourists of all ages and social classes. Ensure that public spaces are of high quality to accommodate intensive use.

- Principle 6 - Public Private Partnerships speed up the process

Development of new waterfronts should be planned on a public-private partnership basis. Public authorities must guarantee high quality design, land development, and social sustainability. Private investors should be involved in the transformation process from the outset to ensure market intelligence and accelerate land development. Coordinators of comprehensive water front development must ensure long-term economic, social and environmental benefits.

- Principle 7 - Public participation is part of sustainability

The City's community should be informed and engaged in the discussion continuously from the beginning of the water front transformation process.

- Principle 8 - Water front transformations are long-term projects

Water front projects are challenging for more than one generation and must be transformed in stages so that the entire city and all its residents can benefit from the potential of waterfront spaces, and these require sensitive creation of public spaces, diverse forms of architecture and art and green structures.

- Principle 9 - Revitalisation is a continuous process

Local plans must be based on detailed analyses of the leading functions and content of the waterside landscape. Planning flexibility to adapt to significant changes is important.

- Principle 10 - Water fronts are part of international structures.

Rebuilding water fronts is a very complex task and requires the participation of professionals from many disciplines. The transfer of knowledge and exchange of experience at the international level between actors involved in the water front transformation process at different levels and stages of planning, design and implementation is extremely important.

The assumptions of integrated development of urban waterfronts are in line with the main concepts of urban development in the postindiustrial period. This process is a manifestation of reurbanization and is in competition with suburbanization.
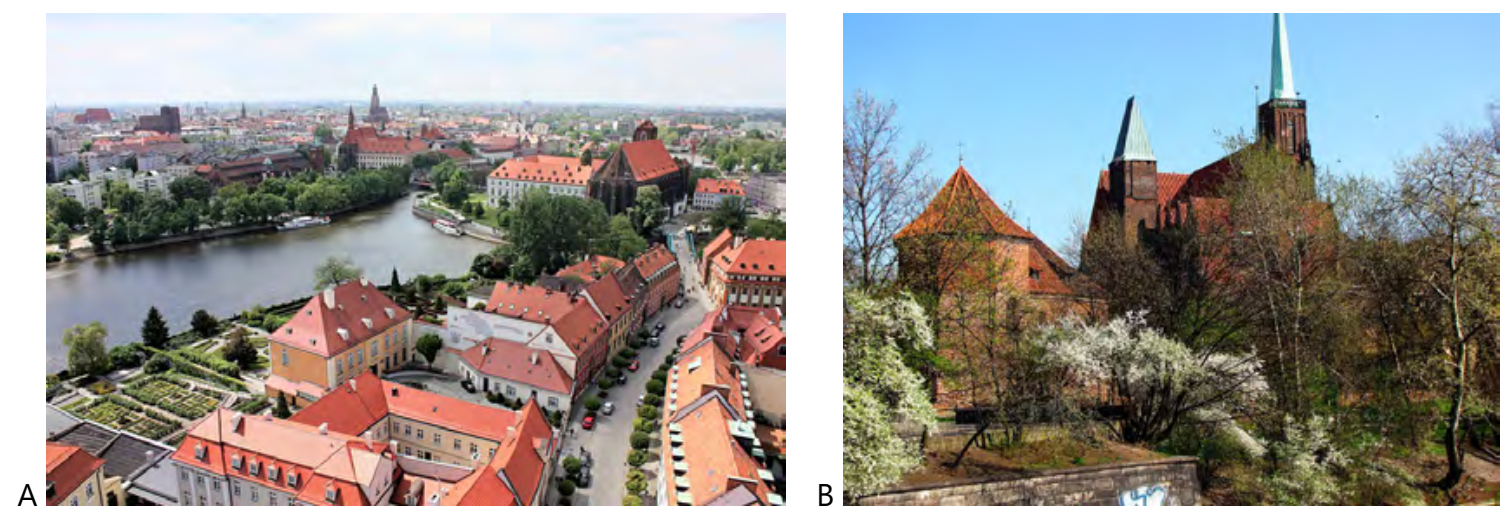

Fig. 7. A - The water area on Ostrów Tumski in Wrocław, B - View on Aleksander Zienkiewicz Boulevard in Wrocław Sources: https://commons.m.wikimedia.org/wiki/File:598563_Wroc\%C5\%82aw_zesp\%C3\%B3I_urbanistyczny_Ostrowa_Tumskiego_05.JPG\#mw-jump-to-license, 17.06.2021, https://pl.m.wikipedia.org/wiki/Bulwar_ks._Aleksandra_Zienkiewicza_we_ Wroc\%C5\%82awiu, 17.06.2021. 

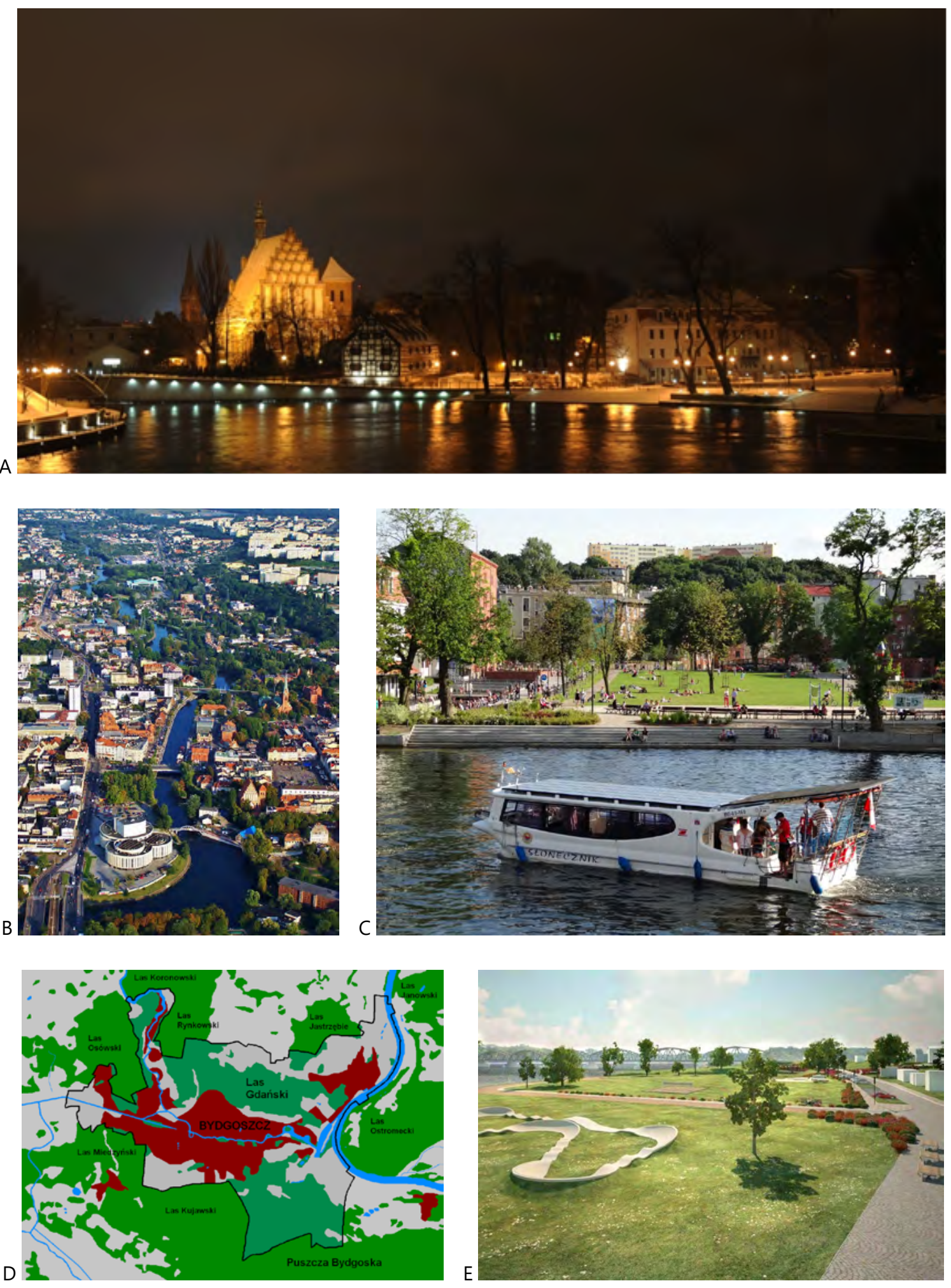

Fig. 8. A - Mill Island - night view, B - Aerial view of Mill Island development in Bydgoszcz, C - Mill Island development, D - Map of the structure of forest areas around the city of Bydgoszcz, E - Developed areas of Old Fordon

Sources: https://visitbydgoszcz.pl/pl/odkryj/co-zobaczyc/1035-wyspa-mlynska, 14.06.2021, https://www.bydgoszcz.pl/ aktualnosci/tresc/rewitalizacja-starego-fordonu-umowa-na-uliczki-p/ 14.06.2021. 
Bydgoszcz is an interesting example of a city whose development was strongly linked to the location of the Vistula and Brda rivers. These rivers, along with the Bydgoszcz Canal, form the hydrographic axis of the city, which decided the final shape of the spatial and functional structure of Bydgoszcz. Development of urban riverside areas against the background of spatial structure of Bydgoszcz is an example of actions towards sustainable development [Fig. 8]. Green corridors, running from the forests surrounding the city, through parks and gardens to green areas stretching along the Brda River, the Vistula River and the Bydgoszcz Canal, provide opportunities for active recreation. The individual layout of river and canal connections, which is the axis of the city's spatial structure, together with the urban and architectural assumptions of water-related areas and the landscape of river valleys and The Torun-Eberswalde Proglacial Valley gives the city an individual look and a unique shape. Such spatial and landscape solutions contribute to enriching the biodiversity of the environment and preserving the cultural landscape and raising the standards of recreational spaces, thus contributing to improving the quality of life in the city.

Table 3. Comparative analysis of green area resources of the largest Polish cities in terms of population

\begin{tabular}{|ccccccc|}
\hline City & $\begin{array}{c}\text { Popula- } \\
\text { tion in } \\
\text { thousands }\end{array}$ & $\begin{array}{c}\text { Surface } \\
\text { area in } \mathbf{~ k m}^{\mathbf{2}}\end{array}$ & $\begin{array}{c}\text { Green area } \\
\text { in } \mathbf{~ k m}^{\mathbf{2}} *\end{array}$ & $\begin{array}{c}\text { City area per } \\
\mathbf{1} \text { inhabitant } \\
\mathbf{~ m}^{\mathbf{2}}\end{array}$ & $\begin{array}{c}\text { Surface area } \\
\text { of greenery } \\
\text { per } \mathbf{1} \text { inhab- } \\
\text { itant } \mathbf{~ m}^{\mathbf{2}}\end{array}$ & $\begin{array}{c}\text { Share of } \\
\text { green areas } \\
\text { in the city } \\
\text { area }\end{array}$ \\
\hline Warszawa & 1790,7 & 517,2 & 77,6 & 288,8 & 43,3 & $15 \%$ \\
\hline Kraków & 779,1 & 326,9 & 49,1 & 419,6 & 63,0 & $15 \%$ \\
\hline tódź & 679,9 & 293,3 & 55,7 & 431,4 & 81,9 & $19 \%$ \\
\hline Wrocław & 642,9 & 292,8 & 52,7 & 455,4 & 82,0 & $18 \%$ \\
\hline Poznań & 534,8 & 261,9 & 52,4 & 489,7 & 98,0 & $20 \%$ \\
\hline Gdańsk & 470,9 & 262,0 & 28,8 & 556,4 & 61,2 & $11 \%$ \\
\hline
\end{tabular}

Data for 2019 according to CSO

* Green area excluding allotment gardens, cemeteries and agricultural areas (source GUS)

Source: study by Tomczak P.

Table 4. Structure of green areas in the biggest Polish cities

\begin{tabular}{|c|c|c|c|c|c|c|c|c|c|c|}
\hline \multirow[b]{2}{*}{ City } & \multicolumn{2}{|c|}{ Parks } & \multicolumn{2}{|c|}{ Greens } & \multicolumn{2}{|c|}{ Estate greenery } & \multicolumn{2}{|c|}{ Street greenery } & \multicolumn{2}{|c|}{ Total } \\
\hline & 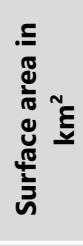 & 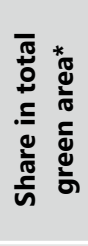 & 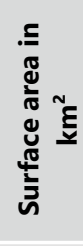 & 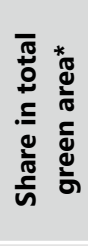 & 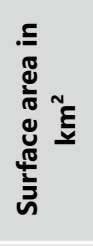 & 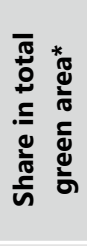 & 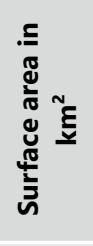 & 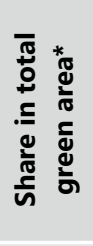 & 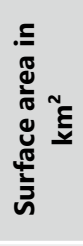 & 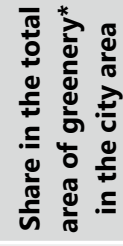 \\
\hline Warszawa & 9,31 & $1,8 \%$ & 2,59 & $0,5 \%$ & 20,69 & $4,0 \%$ & 12,93 & $2,5 \%$ & 45,52 & $8,8 \%$ \\
\hline Kraków & 4,58 & $1,4 \%$ & 2,61 & $0,8 \%$ & 9,81 & $3,0 \%$ & 6,21 & $1,9 \%$ & 23.21 & $7,1 \%$ \\
\hline Łódź & 6,45 & $2,2 \%$ & 0,88 & $0,3 \%$ & 9,97 & $3,4 \%$ & 6,45 & $2,2 \%$ & 23,75 & $8,1 \%$ \\
\hline Wrocław & 7,61 & $2,7 \%$ & 5,56 & $1,9 \%$ & 5,86 & $2,0 \%$ & 5,56 & $1,9 \%$ & 24,59 & $8,5 \%$ \\
\hline Poznań & 3,40 & $1,3 \%$ & 0,78 & $0,3 \%$ & 6,28 & $2,4 \%$ & 9,69 & $3,7 \%$ & 20,15 & $7,7 \%$ \\
\hline Gdańsk & 2,10 & $0,8 \%$ & 1,57 & $0,6 \%$ & 4,72 & $1,8 \%$ & 2,62 & $1,0 \%$ & 11,01 & $4,2 \%$ \\
\hline
\end{tabular}

* Green area excluding forests, allotment gardens, cemeteries and agricultural land (source CSO data for 2019)

Source: study by Tomczak P. 
For a representative group of six major Polish cities: Warsaw, Krakow, Łódź, Wrocław, Poznań, and Gdańsk, we conducted a study in which we determined the following four coefficients: the area of greenery per square kilometer, the city area per capita, the area of greenery per capita, and the share of greenery in the city area [Table 3].

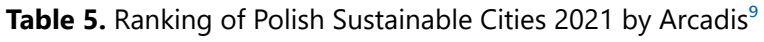

\begin{tabular}{|c|ccc|}
\hline City & $\begin{array}{c}\text { Position in the general } \\
\text { classification }\end{array}$ & $\begin{array}{c}\text { Position in area } \\
\text { classification: environment }\end{array}$ & $\begin{array}{c}\text { Ranked as the greenest city } \\
\text { in the world by HUGS** }\end{array}$ \\
\hline Warszawa & 1 & 42 & 22 \\
\hline Kraków & 19 & 50 & 5 \\
\hline tódź & 36 & 39 & - \\
\hline Wrocław & 12 & 41 & - \\
\hline Poznań & 5 & 36 & - \\
\hline Gdańsk & 8 & 24 & - \\
\hline Koszalin & 11 & 1 & - \\
\hline Grudziądz & 44 & $2^{*}$ & \\
\hline Gdynia & 29 & $2^{*}$ & \\
\hline * Equivalent items & & & \\
\hline ** Husqvarna Urban Green Space Index & Ranking the World's 100 Greenest Cities \\
\hline
\end{tabular}

Source: https://inzynieria.com/budownictwo/rankingi/61161,oto-najbardziej-zrownowazone-miasta-w-polsce, 14.06.2021; https://inzynieria.com/budownictwo/rankingi/60537,najbardziej-zielone-miasta-swiata, 14.06.2021.

Table 6. Ranking of Polish cities with county rights with the highest share of green areas in the city area in 2015

\begin{tabular}{|c|ccc|c}
\hline Position & City & Total green areas & $\begin{array}{c}\text { Parks, greens, housing } \\
\text { estate and street } \\
\text { greenery }\end{array}$ & Forests \\
\hline 1 & Sopot & $58 \%$ & $6 \%$ & $52 \%$ \\
\hline 2 & Zielona Góra & $46 \%$ & $2 \%$ & $43 \%$ \\
\hline 3 & Katowice & $46 \%$ & $6 \%$ & $39 \%$ \\
\hline 29 & Gdańsk & $20 \%$ & $2 \%$ & $17 \%$ \\
\hline 30 & Warszawa & $19 \%$ & $5 \%$ & $13 \%$ \\
\hline 31 & Poznań & $18 \%$ & $4 \%$ & $14 \%$ \\
\hline 35 & tódź & $14 \%$ & $5 \%$ & $9 \%$ \\
\hline 43 & Wrocław & $12 \%$ & $4 \%$ & $7 \%$ \\
\hline
\end{tabular}

Ranking based on CSO sources prepared by BIQdata and MojaPolis

Source: https://biqdata. wyborcza. pl/biqdata/7,159116,22065709,sprawdz-jak-bardzo-zielone-jest-twoje-miasto. html, 14. 06. 2021. 
In another study for the above six Polish cities, we conducted quantitative analyses for four representative forms of greenery: parks, greens, residential greenery and public greenery [Table 4].

The National SDG Reporting Platform, reports that urban green space per capita in Poland in 2019 is $22.2 \mathrm{~m}^{2}$. Thus, the value is significantly lower than the area in the surveyed largest Polish cities.

At the beginning of 2021, a report was published on the second edition of the ranking of the 50 largest Polish cities in terms of their actions complying with the idea of sustainable development. The ranking prepared by Arcadis, an international company providing analytical, consulting and design services for the environment, infrastructure and construction, took into account three areas: environmental, economic and social [Table 5].

We also examined selected district towns in terms of the total number of green areas, the total number of areas of four representative forms of greenery (park, greenery, housing estate and street greenery) and the number of forest areas. In the ranking of cities, cities from the representative group - Warsaw, Kraków, Łódź, Wrocław, Poznań, Gdańsk - were included for comparison [Table 6].

\section{Results}

Our research and analyses of rankings of foreign cities [Tables 1 and 2] indicate that the share of green areas in cities which have been recognised as the greenest cities in the world is about $60 \%$ of the area of these cities (57-68\%). The area per capita in $\mathrm{m}^{2}$ is more diversified and ranges from $182.6 \mathrm{~m}^{2}$ to $560.1 \mathrm{~m}^{2}$. The population density of the city is of great importance here, as in the case of Charlotte the area of the city per capita is as large as $830 \mathrm{~m}^{2}$ and in the other cities it averages around $374 \mathrm{~m}^{2}$ (309.6-426.9). The next tree canopy cover ratio we studied allows us to conclude that in sustainable cities, this value averages about $28 \%$ of the city area (23.7-36.1).

Our research [Tables 1, 2, 3 and 4] was confronted with the results of rankings created for Polish cities and with rankings created by foreign companies which include Polish cities. From the study of a representative group of six selected Polish cities [Table 3] it results that the share of green areas in the area of these cities is almost three times lower than in the studied foreign cities [Tables 1 and 2] and is at the average level of approx. $16 \%$. A consequence of this is a much smaller size of green areas per one inhabitant, on average about $72 \mathrm{~m}^{2}$. However, it should be noted that the presented data were obtained from the Central Statistical Office (GUS), which balanced the areas of urban greenery without allotment gardens, cemeteries and greenery on agricultural land. Thus, the values of the coefficients discussed above may in fact be higher. In this situation, comparing the values of the discussed characteristic coefficients for Polish and foreign cities will not be objective, as in the case of foreign cities, due to the tools used (Google Street View (GSV) panoramas and analysis of satellite images), the data concern all areas of urban greenery.

The results of the study presented in Table 4 show large differences between the areas of the four studied forms of urban greenery in terms of their size and share in the area of the cities in the representative group. In the group of parks the biggest differences were noted between Warsaw and Gdańsk. In the group of green areas, Poznań has the lowest values and Kraków the highest. In the case of residential greenery the extreme values were again reached by Warsaw and Gdańsk, while in the group of street greenery Warsaw was in first place and Gdańsk recorded the lowest value. In total, Warsaw has the largest area of green areas $\left(45.52 \mathrm{~km}^{2}\right)$ and Gdańsk has four times less $\left(11.01 \mathrm{~km}^{2}\right)$, but the differences are not so big when we examine the shares of these areas in urban areas. Warsaw reaches here the value of $8.8 \%$, which is comparable in this respect with 4 cities (Cracow, Łódź, Wrocław and Poznań), and only Gdańsk has this coefficient twice lower. The average value of the share of landscaped areas in this study for the representative group is $7.4 \%$ of the city area.

Only three cities out of six Polish cities examined by us were included in the international ranking of the greenest cities in the world according to HUGS [Table 5]. These were Warsaw, Krakow and Wroclaw. Best in this classification was Krakow, which took $5^{\text {th }}$ place and Warsaw and Wroclaw ranked 22 and 23.

In the ranking of Polish cities with county rights with the highest share of green areas in the city area in 2015 [Table 6], the highest place was taken by Sopot, where the total share of green areas was $58 \%$, forests $43 \%$ and four forms of urban greenery - parks, greens, residential greenery and street greenery together occupied $6 \%$ of the city area. Out of the six largest Polish cities we studied, Krakow fared the worst in this ranking, taking $49^{\text {th }}$ place with a share of green areas at $9 \%$, four forms of urban greenery at $4 \%$ and forests at $4 \%$. 
Comparison of the results for Kraków from 2015 and 2021, shows how intensive actions have been taken in Kraków in terms of green areas, as already in 2021 in the ranking of the greenest cities in the world according to HUGS Kraków was in $5^{\text {th }}$ place.

Important elements in terms of implementing the idea of sustainable development are also the activities undertaken for the benefit of increasing the area of open waters in urbanised areas. We are seeing an increase in the proportion of water surface in urban areas. The process of enlarging water areas is associated with considerable financial outlays and is much slower than activities aimed at enlarging and arranging green areas. The situation is different in the case of cities with a well-developed hydrographic system, in which there are numerous waterside areas generating possibilities of managing those areas for the benefit of sustainable development.

In our opinion, the coefficients presented above can to a large extent be regarded as characteristic indicators of the degree of the city's development in line with the idea of sustainable development.

\section{Summary and conclusions}

Actions for sustainable development in the urban landscape take different forms and scopes of area and theme. They concern both degraded and post-industrial areas, as well as uninvested areas where new urban structures are planned.

The presented examples of urban areas show that there are many aspects to urban landscape development and improvement activities, both legal, environmental, social and economic. Linking and maintaining appropriate relations between the above mentioned factors is the main principle of sustainable landscape planning and spatial and economic development of cities. They can serve as models of spatial and landscape solutions for other cities, areas and regions.

Trees play an extremely important role in a sustainable environment and are not adequately acknowledged in many rankings. The area of land on which it grows can be relatively small, while the crown forms a canopy many times larger, limiting the city's heating during summer periods. It retains water, neutralizes pollutants (an average-sized tree neutralizes in a year the toxic compounds resulting from burning about 130-150 liters of gasoline. It provides a noise screen and brakes the wind. At the same time, it produces phytoncides - substances that inhibit the growth of bacteria and fungi.

The legal definition of green areas in Polish legislation is very vague and leaves a lot of room for interpretation. In addition, municipalities often do not have a properly maintained inventory of these areas. Therefore, analyses are usually based on CSO data, which are as vague as their definition contained in the Environmental Protection Act of 16 April 2004.

The analysis covered the six largest Polish cities in terms of population and compared them with selected cities in the world. Both in Poland and in the world there are many rankings of the greenest cities. The results of these studies often vary greatly depending on the criteria used. Some of them assume an objective value of the green area, or more often its percentage share in the city area. But again, different criteria are adopted. Sometimes only public greenery is taken into account, other times also natural greenery or agricultural areas, and very rarely greenery on private land, which also has a huge impact on the environment and is an important element of the system of sustainable city development, is taken into account. When planning urban investments, the greatest influence of the authorities is visible within the area of arranged greenery and municipal resources. Through appropriate regulatory or protective legislation, privately owned lands can also be indirectly affected.

Urban development results in development and urbanization of green areas. The analysis of this tendency in the largest cities proves that it takes place mainly at the expense of agricultural areas, although it often happens that developer developments encroach on green areas, especially at the expense of residential greenery. However, the spatial policy pursued in accordance with the idea of sustainable development of the urban landscape compensates for the loss of greenery in many cases by afforestation of wasteland or creation of new areas of organised greenery in revitalised (post-industrial) areas, coastal areas, completion of street greenery, implementation of new parks and green areas, and by organisation of new forms of greenery on former farmland.

The conclusions of the analyses are largely consistent with the 2017 NIK audit report on urban greenery management in selected Polish cities.

- Lack of unambiguous and unified definitions of green spaces. 
- Lack of unambiguous criteria for evaluating particular areas within the concept of a sustainable city.

- Territorial units pay too little attention to social interests resulting from environmental protection, preferring investors' interests.

- Lack of or inadequate knowledge by local governments of the area, biodiversity, planting and removal of trees and shrubs in the administered area.

- The increase in green space per capita is not due to an increase in green space, but to a decrease in population.

- Most of the large Polish cities are implementing and improving procedures aimed at sustainable development and ensuring balance between social, economic and community areas, also by increasing the area of greenery.

- The low ratio of green areas per one inhabitant in cities is mainly generated by small cities, which often do not have adequate greenery.

- Actions aimed at not only protecting the existing urban landscape but also, where possible, enhancing its value should include a range of correlated legislation and integrated actions.

- First of all, negative actions in the spatial and landscape sphere caused by badly constructed law should be stopped and removed, and then effective law should be enacted in order to repair the deformed, damaged areas and those in need of remedial actions. According to the authors, in this situation it is necessary to determine a package of unambiguous requirements for the establishment of an efficient legal apparatus for sustainable development.

- It is necessary to introduce changes in the currently binding laws (on spatial planning and development, landscape law, revitalization law and additional laws) providing for greater protection of areas valuable for landscape and creating precise guidelines for effective actions in this respect. It is necessary to amend the above-mentioned laws, among others, in terms of defining landscape dominants and excluding from legal use the extremely destructive procedure for space: the so-called WZ - Decision on Conditions of Development and Land Use (WZiZT), which allows pathological freedom in interpreting the parameters of the environment and setting the rules for new development. Among other things, this is due to the fact that the findings of the WZiZT do not have to be consistent with the provisions of the Study of Conditions and Directions of Spatial Development for a given area. Decisions on WZiZT subjected to the pressure of investors and decision makers lead in many cases to irreversible destruction and distortion in the sphere of space and landscape.

- The area of actions for the benefit of sustainable development should be equipped and enriched with much more competences in the field of making and passing legal acts concerning development and spatial management in the local and strategic scope. In this respect, efforts to increase the participation of specialists in landscape architecture, architecture and urban planning in decision-making, economic and planning bodies at all levels of local and global administration should be essential.

- There is a need to create a law enabling the establishment of a strong professional self-government that will bring together, focus and represent the scientific and professional circles of landscape architecture, spatial planning, architecture and urban planning. Such a strong representation and joint action of all circles whose professional, creative and scientific activity concerns the shaping of space should be equipped with adequate competencies in terms of co-determining the law and spatial and economic policy of the country, with particular emphasis on sustainable development, landscape protection and cultural values.

- It is also necessary to consistently enforce the already existing legal provisions regarding the requirement to develop and apply landscape audits, on the basis of which there should be compulsory implementation of unambiguous and consistent criteria for assessing the value of urban areas due to their particularly valuable landscape, environmental, cultural and social values.

- Another aspect of enforcing the requirement for landscape audits is the obligatory implementation of procedures that would strictly protect the most valuable areas against activities that could contribute to their degradation and disturb the existing urban greenery system or adversely interfere with the landscape.

- In this respect it is of utmost importance to define precise and coherent ranges of competencies for individual levels of state administration in relation to planning, management of urban green areas and 
shaping urban structures in the aspect of sustainable development, and first of all to eliminate the unfavourable phenomenon of congruence between responsibility and authority in landscape and spatial management.

- Efforts to continually increase green spaces and revitalize existing ones should be intensified. To this end, it is necessary to return to the old urban planning norms applied in the planning of development sites, which defined the minimum area of functional areas and green areas accompanying newly designed buildings and architectural complexes. They set out the minimum quantitative and spatial indicators in relation to the number of inhabitants and the area of development, e.g. the former parameter: $8 \mathrm{~m}^{2}$ of green areas per one inhabitant. In the opinion of the authors, for the purposes of sustainable development, this parameter should be set at the level of $10-15 \mathrm{~m}^{2}$ of high green areas per one resident and surface waters at the level of $3-5 \mathrm{~m}^{2}$ per one resident.

- Efforts should be intensified to raise public awareness in the field of environmental protection, both through school education, self-governmental education and the activities of the media and other opinion-formers. This should concern environmental protection understood in a comprehensive way, i.e. landscape, energy efficiency of buildings, waste management, reduction of water consumption, use of renewable sources in the energy sector and thus reduction of $\mathrm{CO}_{2}$ emissions. Developed public awareness may be conducive to exerting appropriate pressure on decision-makers, designers and investors so that economic aspects are not given priority over ecological, landscape and social values.

\section{Literature}

[1] Bać A., Zielone miasta" jako szansa na zrównoważony rozwój na przykładzie Vancouver, Politechnika Wrocławska, 2012.

[2] Bać A., Współczesny wizerunek Vancouver - polityka, edukacja i architektura, Zeszyty Naukowe Politechniki Poznańskiej, Architektura i Urbanistyka, 2013, z. 29, 17-23.

[3] Bać A., Idea zrównoważenia i jej wybrane przejawy, Architectus, 2014, 2(38).

[4] Bukowski Z., Pojęcie zrównoważonego rozwoju w prawie polskim, [w:] Zrównoważony rozwój od utopii do praw człowieka, Papuziński A. (red.), Bydgoszcz 2005.

[5] Bukowski Z., Zrównoważony rozwój w systemie prawa, Toruń 2012.

[6] Chmielewski T.J., Myga-Piątek U., Solon J., Typology of current landscapes Polish. Geographical Review, 2015, 87(3), 377-408.

[7] Górka A., On the utility of the village vision, In: Gosidło K., Twardoch A. (eds.), Architecture, environment, society, contemporary economy (pp. 84-97), Gliwice: Wydawnictwo Politechniki Śląskiej, 2017.

[8] Halamska M., Poland: a new shape of rural-urban relations, Yearbooks of Rural Sociology, 2006, 26, 138-162.

[9] Halamska M., Rural transformation. Warsaw: Development Academy EUROREG Regional Advisory Council, Warsaw University, 2008.

[10] Jakub P., Magee L., Scerri A., Steger M.B., Zrównoważony rozwój miast w teorii i praktyce: kręgi zrównoważonego rozwoju, 2015, Londyn: Routledge.

[11] Januchta-Szostak A., Miasto w symbiozie z wodą (Town and Water Symbiosis), Czasopismo Techniczne, Architektura, 2010, R. 107, z. 14, 6-A2, 95-102.

[12] Łodzinski P., Continuation of regional tradition in single-family residential architecture as one of the conditions of spatial order, Architecture et Artibus, 2012, 1, 18-24.

[13] Łuczyńska-Bruzda M., Natural elements of the environment (4 $4^{\text {th }}$ ed.), Kraków: Wydawnictwo Politechniki Krakowskiej, 1997.

[14] Małachowicz E., Conservation and revalorization of architecture in cultural environment (4 ${ }^{\text {th }}$ ed.), pp. 21-503, Wrocław: Oficyna Wydawnicza Politechniki Wrocławskiej, 2007.

[15] Matuszkiewicz W., Guide to the identification of plant communities of Poland, Warsaw: Wyd. Science, PWN, 2001.

[16] Muszyńska-Jeleszyńska D., Tereny nadrzeczne w aspekcie rozwoju i rewitalizacji miast. Uniwersytet Kazimierza Wielkiego, 2013, http://repozytorium.ukw.edu.pl/handle/item/1446.

[17] Myga-Piątek U., Landscape policy of Poland - at the threshold of implementation, Overview Geographic, 2015, 87(1), 5-25.

[18] Nawrotek E., Ochrona bioróżnorodności a nowe rozwiązania prawne w zakresie ochrony terenów zieleni i zadrzewień, Studia luridica Lublinensia vol. XXVI, 1, 2017, DOI: 10.17951/sil.2017.26.1.315. 
[19] Olejniczak E., Zasada zrównoważonego rozwoju w systemie prawa polskiego - wybrane zagadnienia. Przegląd Prawa Ochrony Środowiska 2016, 2, DOI: http://dx.doi.org/10.12775/PPOS.2016.013.

[20] Przesmycka E., Spatial and architectural transformations of degraded and restored towns in the Lublin region, In: Degraded and restituted towns in Poland: origins, development, problems = Cities degraded and restituted in Poland: origins, development, problems (eds.) Krzysztofik R., Dymitrov M., Gothenburg: University of Gothenburg, 2015, pp. 209-247.

[21] Przesmycka E., Napieralska Z.Z., City landscape: present state and problems with protection of post-war single family house complexes from uncontrolled modernizations, w: Landscape as impulsion for culture: research, perception \& protection, Vol. 3, Problems of protection \& sharing (eds. Kołodziejczyk P., Kwiatkowska-Kopka B.), Kraków: Institute of Archeology. Jagiellonian University in Kraków, Institute of Landscape Architecture. Cracow University of Technology, 2016, s. 99-108.

[22] Richling A., Solon J., Landscape ecology (4th ed.), Warsaw: Wyd. Science, PWN, 2002.

[23] Roszkowska E., Filipowicz-Chomko M., Ocena realizacji koncepcji zrównoważonego rozwoju województw Polski w zakresie poziomu rozwoju społecznego w roku 2005 oraz 2013, Optimum, Studia ekonomiczne, 2016, 3 (81).

[24] Rylke J., Principles of cultural landscape assessment, In: Szyszko j., Rylke J., Jeżowski P. (eds.), Assessment and valuation of natural resources (pp. 214-235), Warsaw: SGGW Publishing House, 2002, 224.

[25] Rylke J., Cultural Landscape. Maps of Meaning, In: Bernat S. (ed.), Intangible values of cultural landscapes (pp. 278-287), Sosnowiec: Cultural Landscape Commission PTG, 2011.

[26] Rylke J., The cultural landscape of Poland, In: Assessment and valuation of natural resources (pp. 224-240), Warsaw: Wyd. SGGW, 2013.

[27] Rylke J., The natural context of landscape design. Bionics 40, In: Dreszer S. (ed.), 40 years of bionics at the University of Arts in Poznań. Landscape design as an indispensable part of natural environment protection, Poznań: University of Arts in Poznań, 2016.

[28] Stangel M., Kształtowanie współczesnych obszarów miejskich w kontekście zrównoważonego rozwoju, Gliwice, Wydawnictwo Politechniki Śląskiej 2013.

[29] Stoczkiewicz M., Zasada zrównoważonego rozwoju jako zasada prawa, Prawo i Środowisko 2001, 1.

[30] Szmytke R., Methods of analysis of morphology and physiognomy of settlement units, Wrocław: University of Wrocław, 2014.

[31] Szulc H., Morphogenesis of rural settlements in Poland, Warsaw: PAN, 1995.

[32] Szumigała P., Spatial codes in the context of sustainable development of selected communes of Wielkopolska. Zeszyty Naukowe Uniwersytetu Szczecińskiego, Studies and Papers of the Faculty of Economic Sciences and Management, $2015,42(2), 219-232$.

[33] Szumigała P., Space management and management in the context of sustainable development - Diagnosis of the state of space in Poland. In Farming in the $21^{\text {st }}$ century (96-111), Szczecin: Wyd. University of Szczecin, 2016.

[34] Szumigała P., Diagnosis of the state of protection of historical urban structures-landscape areas of Poznań district on the basis of Historical Spatial Codes method and records of local spatial management plans, Poznań, Publishing House of the University of Life Sciences in Poznań, 2019, 387.

[35] Teneta-Skwiercz D., Wskaźniki pomiaru zrównoważonego rozwoju - Polska na tle krajów Unii Europejskiej. Prace naukowe Uniwersytetu Ekonomicznego we Wrocławiu, Research papers of Wrocław University of Economics, $2018,516$.

[36] Tkocz J., Spatial organization of villages in Poland, Katowice: Wydawnictwo Uniwersytetu Śląskiego, 1998.

[37] Trocka-Leszczynska E., Architectural identity of rural housing in the Sudeten region, Quarterly Journal of Architecture and Urban Planning, 2001, 46(3), 299-308.

[38] Trocka-Leszczynska E., Nykiel J., Possibilities of preserving the features of regional architecture in Kotlina Kłodzka, Building Materials, 2015, 11, 169-171.

[39] Trzeskowska E., Ochrona różnorodności biologicznej w miastach jako jedna z zasad wdrażania zrównoważonego rozwoju, Studia miejskie, 2015, tom 19.

[40] Wagner I., Januchta-Szostak A., Waack-Zając A., Narzędzia planowania i zarządzania strategicznego wodą w przestrzeni miejskiej Zrównoważony Rozwój - Zastosowania nr 5, 2014.

[41] Wolski P. (ed.), Protection of natural and cultural heritage in Poland, Warsaw: SGGW Publishing House, 1998.

[42] Żarska B., Study of landscape protection - methodics of working out for various areas, Annals of Warsaw University of Life Sciences - SGGW, Horticulture and Landscape Architecture, 2001, 22, 111-122.

[43] Żarska B., Landscape Conservation (ed. II zm, pp. 11-183), Warsaw: SGGW, 2003. 


\section{Legal acts}

[1] Ramsar Convention, adopted in Ramsar in 1971.

[2] Paris Convention for the Protection of the World Cultural and Natural Heritage, adopted in Paris on 16 November 1972 , OJ 1976 No. 32, item 190.

[3] Washington Convention - also known as the CITES Convention, adopted in Washington in 1973.

[4] Berne Convention on the Conservation of European Wildlife and Natural Habitats, 19 September 1979.

[5] European Convention for the Protection of the Archaeological Heritage, done at La Valetta on January 16, 1992, Journal of Laws 1996, No. 120, item 564.

[6] The Bonn Convention on the Conservation of Migratory Species of Wild Animals was drawn up in Bonn on 23 June 1979 and the ASCOBANS and EUROBATS Agreements.

[7] Convention on Biological Diversity of Rio de Janeiro of 5 June 1992, OJ of 6 November 2002.

[8] The European Landscape Convention, done at Florence on 20 October 2000, OJ of 2006. No. 14, item 98.

[9] List of Biosphere Reserve Network Areas.

[10] World Heritage List.

[11] Agenda 2030.

[12] Constitution of the Republic of Poland of 2 April 1997.

[13] Act of 24 April 2015, amending certain laws in connection with the strengthening of landscape protection tools (Journal of Laws 2015, item 774).

[14] Act on revitalization and amendments to some other acts of 9 October 2015 (Journal of Laws 2015, item 1777).

[15] The Nature Conservation Act of 16 April 2004 sets out the objectives, principles and forms of protection of animate and inanimate nature and landscape.

[16] Law on the Protection and Shaping of the Environment of 31 January 1980.

[17] Hunting Law of 13 October 1995.

[18] Carpathian Convention, the Framework Convention on the Protection and Sustainable Development of the Carpathians, made in Kiev on 22 May 2003, was ratified by Poland in 2006 (Journal of Laws 2007, No. 96, item 634).

\section{Idea rozwoju zrównoważonego w krajobrazie współczesnych miast}

Streszczenie: W artykule podjęto próbę omówienia rozwoju idei zrównoważonego rozwoju w krajobrazie miast na wybranych przykładach. Analizie podano przyczyny obecnego stanu krajobrazu miast. Dokonano przeglądu aktów prawnych unijnych i polskich w zakresie ochrony krajobrazu, środowiska i dziedzictwa kulturowego. Zaprezentowane w artykule przykłady wskazują na to, że działania w zakresie rozwoju i poprawy krajobrazu miast mają wiele aspektów, zarówno prawnych, środowiskowych, społecznych i ekonomiczno-gospodarczych. Aktualny rozwój miast powoduje zabudowywanie i urbanizowanie już istniejących terenów zieleni i terenów rolnych. Tymczasem polityka przestrzenna (w myśl idei zrównoważonego rozwoju krajobrazu miast) próbuje kompensować w wielu przypadkach ubytki zielni poprzez zalesianie nieużytków, tworzenie nowych obszarów zieleni urządzonej: na terenach podanych rewitalizacji (poprzemysłowych), terenach nabrzeżnych, wprowadza uzupełnienia zieleni ulicznej oraz realizację nowych parków i zieleńców i organizowanie nowych form zieleni na obszarach byłych użytków rolnych.

Słowa kluczowe: zrównoważony rozwój, krajobraz miejski, akty prawne, dziedzictwo kulturowe, ochrona krajobrazu 